\title{
A critical debate of the cultural and social effects of Valletta 2018 European Capital of Culture
}

\author{
Ebejer John ${ }^{1,2}$, Xuereb Karsten ${ }^{1}$ and Avellino Marie ${ }^{1}$ \\ ${ }^{1}$ Institute for Tourism Travel and Culture, University of Malta, Malta \\ ${ }^{2}$ Corresponding author:email john.ebejer@um.edu.mt
}

\begin{abstract}
:
The paper considers the hosting of the European Capital of Culture in Malta in 2018 in the light of the cultural and social effects on Malta's capital city, Valletta. Governance and impacts on Malta's tourism are also debated. The cultural sector was positively impacted with a varied and innovative programme. The expectations for Valletta 2018 was that the cultural scene in Malta would be taken to a much higher level. This did not happen largely because politicisation undermined the overall governance of the event. In the last two decades, ECoC was one of many projects and initiatives that brought about a process of Valletta's regeneration. There are concerns, however, that excessive commercialisation has reduced liveability.
\end{abstract}

Keywords: European Capitals of Culture, Valletta, culture, social impacts, impact on tourism.

This is a pre-publication version of the paper.

For the paper as published refer to the Journal of Tourism and Cultural Change. DOI: 10.1080/14766825.2020.1849240 


\section{Introduction: assessing European Capitals of Culture}

Valletta was declared European Capital of Culture for 2018 in October 2012, thus allowing for a 6-year run-up to the organization of the event which became known as Valletta 2018 (henceforth to be referred to as V18). The period was particularly interesting as the process started in earnest soon after Malta joined the European Union in 2004, with early discussions between Maltese authorities and the European Commission Directorate General for Culture already picking up pace by 2008 and the formation of a local body to steer preparations on a national level in place by 2010. Although the effects of the designation included all the Maltese Islands, Valletta was the focus of the cultural and infrastructural activities that led up to and climaxed during 2018. The bestowed title is a means of bringing Europeans closer together through the valorization of the rich diversity of a common history and values. In the case of V18 it would also provide the capital city with the opportunity to nurture a more culturally nuanced image for international tourists (Bidbook Imagine 18, 2011; Cordina, 2014; Farmaki et al, 2019).

Assessing European Capitals of Culture $(\mathrm{ECoC})$ has developed in an established area of study in its own right. Even before Garcia et al's seminal studies (2010) on the impacts emanating from and surrounding Glasgow, ECoC had already been attracting the attention of researchers in urban regeneration and tourism. While the first years of the title were meant to highlight the existing value of recognizable cities of great cultural import, the designation of Glasgow, arguably a challenging city well below par when compared to standard cultural destinations, brought significant changes to the way the title was given, and later competed for (Palmer, 2004). Research followed suit, with studies in the new millennium in particular ushering in a new way of evaluating the effects of the ECoC against quantifiable and verifiable criteria (Garcia 2005). 
More recently, the evaluation of ECoC by the monitoring panel appointed by the European Commission, and by the cities themselves, have followed suit. A recent example was Aarhus 2017 that ran a rigorous and critical self-assessment. This was a truly independent study carried out by Aarhus University (2018). Another example is Leeuwarden 2018 that set key performance indicators to follow and highlight shortcomings or required changes (Municipality of Leeuwarden \& Province of Fryslân, 2019).

The research refers to various sources including the evaluation report prepared by the European Commission (Fox \& Rampton, 2019). It is supported with the analysis of newspaper reports and opinion pieces in Maltese printed media. The authors looked at items dealing with V18 from reliable Maltese newspapers from 2016 to 2019. Although eventually only a few were cited, they all provided a useful context upon which the authors could reflect to develop the discussion. The research is further backed up by the personal experience of the authors. ${ }^{12}$

Bianchini et al (2013) note a linkage between mega events such as ECoC and urban regeneration. In a context of growing competition between cities, policy makers often consider cultural mega events as part of a strategy to improve the image of a city improve its infrastructure and revitalize its economy. Bianchini et al (2013) note four dimensions of regeneration namely symbolic, economic, physical and social. These dimensions are intertwined and difficult to consider separately. The focus of this paper are two of the dimensions referred to by Bianchini et al namely the symbolic and social effects of V18. The paper analyses these critically and in some

\footnotetext{
${ }^{1}$ The first author has been involved professionally with Valletta for over two decades on urban planning and tourism development. More recently he was an active member of Valletta Alive Foundation, an NGO that lobbied in favour of Valletta. As an activist, he followed closely the ECoC process from before the bidding stage up to now. He also attended several V18 seminars and had discussions with V18 officials at various stages.

2 The second author led preparations for the European Capital of Culture in Malta between 2011 and 2017 in his role first as project coordinator and later as executive director of the foundation purposely set up by national government.
} 
depth referring to various sources as well as the authors' own experience of V18. Cultural and social aspects are also impinged upon by two further dimensions to which Bianchini et al refer namely economic impacts and physical regenerations. The paper also debates impact on tourism and governance as these have implications on the overall debate on cultural and social effects.

\section{European Capital of Culture - A European Experience}

The ECoC's declared objectives are to put cities at the heart of cultural life across Europe and to improve the quality of life in these cities through culture and art. Through participation in yearlong activities, citizens play a bigger role in their city's development and cultural expression and strengthen their sense of community. The ECoC seeks to raise the international profile of host cities and help promote and celebrate different European cultures. The ECoC is much more than putting up 'a year of culture' and the benefits of hosting the year reach further than those directly associated with culture (Fox \& Rampton, 2019). Up to 2018, there were 58 cities or city-regions across Europe that have held the title including the two ECoC for 2018, Valletta and Leeuwarden, the Netherlands (Markwick, 2017). The initiative has become one of the most prestigious and highprofile cultural events in Europe. There is stiff competition between cities to be awarded the title (Bidbook Imagine 18, 2011; European Commission, 2014). For example when Liverpool was awarded the title for 2008, it competed alongside twelve other cities from across the UK (Liu, 2014).

ECoC has developed into arguably the flagship cultural programme of the EU. This is because it requests an ever-growing number of candidate cities to address economic and urban regeneration on the one hand, and social inclusion through civic participation on the other. These 
address two of the main targets of EU Strategy 2020 for economic growth and social wellbeing across the political block. The EU often experiences tensions in trying to pursue social goals while engaging in standard economic practices. Achieving these two goals often proves contradictory for participating cities (Immler and Sakkers, 2014; Lähdesmäki, 2013; O’Callaghan, 2012).

Persons unfamiliar with the ECoC process may perceive it as merely a series of cultural activities that are held in a city in a particular year (Van der Steen \& Richards, 2019). Indeed, the $\mathrm{ECoC}$ is much more than that as reflected by the reasons and objectives that motivate cities to bid for the title. Often ECoC is one of various urban policy tools used by cities to regenerate themselves. Urban renewal is achieved not only by implementing capital projects but also by breathing new life into a city's culture and by boosting tourism. ECoC is a means for raising the international profile of a city, in a context of stiff competition between cities. The more dynamic cities implement strategies to strengthen their attractiveness and hence their competitiveness (Johansson \& Kociatkiewicz, 2011; Campbell, 2011; Quinn, 2005). Cities that are complacent risk losing out and become less renowned when compared to the more dynamic neighbouring cities. ECoC is also supported by the European Commission, which sees it as a celebration of culture and a means for highlighting the richness and diversity of cultures across Europe.

A strong dimension of the project remains its appeal to candidates to be a 'European' city (Sassatelli, 2006).. The ECoC event involved an initial period (1985-1989) when cities were assigned the title as a form of recognition of their cultural value and the focus was on the event itself. Since 1990 the rational for staging the event shifted to one that prioritises the long term effects on city-related matters such as cultural provision, levels of participation and urban development (Smith, 2012; Johansson \& Kociatkiewicz, 2011). More recently, there is a growing awareness of the value of exploiting $\mathrm{ECoC}$ as an opportunity to address citizenship and social 
issues (Van der Steen \& Richards, 2019; Deguara, et al, 2019). Cities bidding for the title still seem to reflect this ambition at the candidacy stage, as can be witnessed by their submitted bidbooks. This European vision is sharpened through the materialisation of the cultural programme of cities that have succeeded in winning the title during the preparation phase, when the advice and guidance of the monitoring panel may be fundamental in defining the final steps towards implementation. However, some cities give little importance to such ideals while giving greater priority to more tangible and deliverable objectives. This is particularly true in relation to the development of infrastructure, increasing growth and jobs and attracting higher numbers of tourists (Monitoring and Advisory Panel, 2017; Žilič-Fišer and Erjavec, 2015).

For large scale events such as ECoC, the long terms impacts are significantly more important than any short term increase in tourism numbers. Long term economic impacts can be achieved in one of two ways. First, ECoC has the potential to significantly alter the way the destination is perceived by a wider international public. For example, the cities of Glasgow, Genoa, Lille and Liverpool (ECoCs in 1990, 2004, 2004 and 2008 respectively) used the event imagery to visually break with the past and as part of narrative of 'rebirth' (Bianchini et al, 2013). Second, ECoC is a vehicle for increased investment in infrastructure, be it cultural, tourism or transport. Lille 2004 for example was characterised by a large scale regeneration programme that included the development of new public spaces, the regeneration of historic buildings and new facilities for the staging of cultural activities (Sacco and Tavano Blessi, 2007).

\section{Malta, Valletta and the European Capital of Culture: Setting the Context}

Malta is located geographically in the centre of the Mediterranean Sea. With a resident population of close to half a million, visited by just under 3 million tourists every year it is one of the most 
densely populated countries in the world. Tourism is a significant contributor to economic activity in Malta (Briguglio and Avellino, 2019). Malta has an unusually rich heritage with historic fortified towns and a series of prehistoric temples. At least for two decades, it has been the government's declared policy of using heritage to increase the share of culture tourists to Malta. In this context, V18 had a particular significance. It provided the opportunity to enhance Malta's credentials as a culture destination. Valletta is strongly associated with culture because of the cultural venues and also because of the history and the built heritage. Malta's main cultural venues are located in Valletta including Teatru Manoel (a baroque theatre dating back to the 1732), the Mediterranean Conference Centre (extensive conference facilities housed in the former hospital of the Knights of St. John), the Centre for Creativity (an arts and culture centre housed in a restored section of the fortifications) and an open air performance space (housed in the restored ruins of the former Royal Opera House). Each is unique in its own particular way.

Valletta's urban heritage gives it a distinctive identity. Valletta's streetscapes communicate a Maltese identity through the distinctive doorways and timber balconies and the extensive use of Maltese stone. Urban fabric also communicates an international identity as the many administrative, residential, cultural and religious buildings are visible reminders of the Order of St. John (Smith and Ebejer, 2012). Urban heritage also refers to the urban spaces within the historic setting. Valletta's grid-iron street layout was based on the new town planning concepts that were popular with the urban planners of the mid-sixteenth century (Ebejer, 2018). Coupled with its location on a peninsula, Valletta's fortifications provide a well-defined perimeter that further reinforces the City's distinctive identity. The fortifications are impressive both for their extent as well as for their height. Valletta's cultural value was recognised with its designation as a World Heritage Site by UNESCO in 1980. Many small walled towns across Europe have become 
‘time-frozen' with significant urban heritage value but little or no urban life (Bruce and Creighton, 2006). Valletta on the other hand needs to reconcile the protection urban heritage with the needs of modern-day living. Valletta constantly needs to adapt to changing needs, within the constraints set by its urban and cultural heritage (Ashworth \& Tunbridge, 2017).

Prior to 2006, it was widely recognised that Valletta needed to be regenerated. There was an evident process of decline with more and more properties being left unused and allowed to decay. Valletta was given low priority by successive governments. Investment was limited to mostly minor restoration projects. The lack of public investment was mirrored by a lack of private investment, creating a downward spiral and more dilapidated properties in many parts of Valletta. After 2006, the regeneration process accelerated with a series of projects. Many historic buildings in Valletta had their facades restored creating much more pleasant streetscape. Significant projects in Valletta included the extension of pedestrian areas to all Valletta centre streets, the restoration and reuse of Fort St. Elmo and the City Gate project. The private sector understood that Valletta offered new opportunities for investment (Ebejer, 2016). Many historic houses and palazzos were restored for use as residences or offices. Preparations for V18 began soon after 2010. This was a further catalyst for more private investment in Valletta particularly in catering establishments and boutique hotels. Increased public and private investment and a richer programme of events was the context within which preparations for ECoC began in 2010. V18 was one of several factors that energised the process of regeneration of Valletta.

The cultural events programme in Valletta and in Malta was greatly enriched over the past two decades (Ebejer, 2018). Notte Bianca ('White Night') was the most notable addition. The first Notte Bianca took place in 2006, and it is now a well-established event in Malta's cultural calendar. Historic buildings, churches, museums and shops remain open till late and streets come 
alive with recitals, opera, jazz, poetry readings, exhibitions, dance, walk tours, street theatre and more. Events are also part of the regenerative process of historic areas. Some Valletta events target a national audience (for example Malta Arts Festival, Science in the City). Others attract an international clientele (International Jazz Festival, International Valletta Film Festival, Valletta Baroque Festival, and Malta Mediterranean Literature Festival). Valletta offers many diverse and interesting open air spaces. Staging with historic buildings backdrop gives added value to the events. Valletta also hosts events that are more closely linked to local culture (Carnival, religious feasts and Holy Week celebrations). In spite a significantly improved cultural calendar since 2000, there is no evidence to show the industry's restructuring towards cultural tourism (Markwick, 2017; Ebejer, 2018).

At bidding stage, between 2010 and 2012, Malta provided the European community with a specific dossier that proposed one city for the title, without other cities in the competition. This was not new. Luxembourg had already experienced this situation, in preparation for its first title in 2006. Soon after EU membership in 2004, Malta introduced much needed new culture-related legislation concurrent with major changes to the way cultural assets, including heritage, were managed. Malta, in its peripheral yet strategic position, bridging North African and Middle Eastern interests with continental ones, exploited its advantages in terms of geopolitics and finance and punched above its weight by linking economic considerations to the development of a brand, based on culture and heritage, for its tourism and investment appeal.

\section{Effects on culture}

Valletta 2018 Foundation was the agency set up by the Government to develop the application and implement the ECoC (henceforth to the referred to as the Foundation). The V18 programme 
included many projects and events that were new or innovative to Malta, including several on contemporary arts and music. V18 presented "a cultural programme during the title-year that featured some events of high-quality and that was more extensive compared to Malta's cultural 'baseline' offering in previous years.” (Fox \& Rampton, 2019: 59). The programme featured 168 projects involving nearly 500 events, including performances by international artists and exhibitions of international. The EC report also claims that V18 contributed to make the cultural offering of Malta more European (Fox \& Rampton, 2019). The print media reported comments on V18 by various stakeholders. On the plus side, the programme was diverse with several Maltese artists having the opportunity to collaborate and gain experience on large international projects. On the minus side, the artistic programme lacked consistency, in part because there was no single artistic director or team. One cultural operator noted that a key element of the bid-book ${ }^{3}$ was ignored namely: the concept of 'Europeanness' and what it means to belong to Europe. This was echoed by another cultural operator who argued that there was a significant difference between the bid-book intentions and the eventual programme. The intention was for a more artist-led approach, with various projects originating from the artistic communities, rather than conceived and controlled by a central government agency. Some made their way to the final programme, but they ended up being marginal events (Reljic, 2019). Similar difficulties were not unique to Valletta 2018 but were also noticeable in many other ECoCs (Palmer, 2014; European Commission, 2018; Hudec et al, 2019). Cultural operators were invited to come forward with ideas for cultural initiatives. This provided them the opportunity to experiment and move out of their comfort zone, as the commercial risks were minimised. The end result was a rich programme of events for the ECoC, even if many events were already part of Malta's cultural programme. The number of new

\footnotetext{
${ }^{3}$ The bid-book is the application upon which Valletta was selected ECoC. It is a commitment of what was to be done and achieved during the $\mathrm{ECOC}$ year.
} 
events, especially innovative ones, was not as much as one would have hoped for. In a context where a reasonable cultural calendar was already well established, the expectations for V18 was that the cultural scene in Malta would be taken to a higher level. This did not materialise and instead in 2018, Valletta and Malta got more of the same. A former member of the selection and monitoring panel reported that, "compared to the bid-book, the final programme had a weaker international dimension". He also noted that "some artistically-interesting projects with an international dimension were reduced in scale or importance or even cancelled.” (Fox \& Rampton, 2019:43). Apart from the change in programme, another concern is the change in the thematic approach. The original four themes of the programme (Generations, Routes, Cities and Islands) were replaced by three new themes. The overall theme of "Imagine 2018" was dropped in favour of the strapline: "Valletta 2018: An island-wide festa" (Fox \& Rampton, 2019). In the organisation of such a complex event, changes are to be expected including changes to the thematic approach. The extent of the changes, however, are very concerning for two reasons. First, the themes were derived through an intensive consultation process with stakeholders prior to the submission of the application. The derived themes were a reflection of the aspirations and expectations of the stakeholders, including the artistic community. Second, Valletta was awarded the title on the basis of the bid-book that was submitted and hence the bid-book was a commitment entered into by the Foundation to the European Commission. Major changes to the themes were in fact a major departure from the Foundation's commitments.

A similar omission may be observed with regard to the digital agenda that is promoted by the EU and also supported on a national level. In local terms, efforts towards integrating technological innovation into cultural expression as a means of engaging with young audiences have improved, and collaborations among entities responsible for culture and science have 
increased. However, in comparison to other ECoCs, efforts in Malta feel underwhelming, especially when models are repeated rather than improved upon through innovation. Furthermore, important linkages between different sectors of the creative industries, including design and technology, are not exploited enough to generate new areas of economic growth and jobs, in line with European and national agendas.

The growth of cultural tourism requires a robust cultural infrastructure and a good programme of events. These can be more effective if they are supported with a strong international cultural image. The mere fact of hosting the $\mathrm{ECoC}$ may have influenced to some extent international perceptions of Valletta and of Malta. V18 was the focus of several international marketing initiatives by the Malta Tourism Authority and this had a role in changing perceptions, albeit it to a very limited degree (Fox \& Rampton, 2019: 57). Malta has a reasonably strong cultural infrastructure. This was further strengthened with the opening of a new purpose designed art gallery, MUZA (Muzew Nazzjonali tal-Arti). Unfortunately however MUŻA was completed and opened to the public at the end of 2018. Sections of the cultural community are concerned that MUŻA will remain underfunded and will also, like other cultural venues, be instrumentalised for political purposes, thus diffusing its cultural and artistic objectives (Xuereb, 2018c).

The perception of V18 amongst the international cultural community was greatly tarnished because of controversial comments made by the Foundation's chairperson. The murder of an investigative journalist, Daphne Caruana Galizia, in October 2017 was a very sensitive topic. In March 2018, the chairperson's comments on social media appeared to mock the memory of the murdered journalist (Fox \& Rampton, 2019: 52). These were deemed to be highly offensive by a significant section of the population, including the local cultural community who called for his resignation. In an open letter to the Prime Minister signed by more than 100 Maltese artists, they 
pointed out that "The role of a chairman of a European Capital of Culture cannot be partisan in attitude and purposely divisive in action.” ('Chairman of committee that', 2018a).

The controversial comments were also noted by V18's international partners, not least because they were divisive and therefore go against the ECoC spirit of inclusiveness. A letter signed by 72 MEPs also called for the Chairman's dismissal. The writers' organisation, PEN International, sent a letter to the European Commission condemning "the behaviour of the management of Valletta 2018" (Fox \& Rampton, 2019:52). The situation deteriorated to the point that the City of Leeuwarden-Friesland (the other ECoC title-holder in 2018) announced that it would not send any official representatives to V18 celebrations.(Leone Ganado, 2018). Moreover, Ulrich Fuchs, the chairperson of the V18 Monitoring and Advisory Panel, denounced V18 and any related event after hearing of the comments of the Foundation's chairperson. Fuchs decided not to attend any event held by the V18 "as long as people who are representing the project destroy European values." ('Chairman of committee that', 2018a). Significantly V18 was also boycotted by the Valletta mayor ('V18 chairman refuses', 2018b).

ECoC is also a celebration of a destination's culture and identity. In doing so a destination would be greatly enhancing its brand and the way it is perceived internationally, especially amongst the cultural communities in European states (Richards and Palmer, 2010). One would have expected this sense of celebration in V18 activities. This was however largely absent in part because of the negative general feeling that V18 Chairman's controversial comments had created (Ebejer, 2019). 


\section{Social impacts of increased tourism activity}

Like many towns and villages across Malta, the social and cultural life of residents revolves around the parishes, the band clubs and the annual parish feast. Many Valletta residents develop strong roots in the City, not least because it gives them a sense of identity. A central element in urban regeneration is the ability of an urban area to retain existing residents so that the social life can be sustained (Ebejer, 2016). It is also essential to attract new residents as this brings in much needed investment in renovation, and subsequently maintenance, of historic properties. Properties which would otherwise decay are restored and brought back into use. Retaining and enhancing a historic area's liveability is therefore central to its regeneration (Allison, 2011).

A study commissioned by the Foundation throws light on the impacts of ECoC on Valletta's livability (Deguara et al, 2019). It is based on interviews with Valletta residents. Interviewees spoke about affordability, with residents claiming that the overemphasis on leisure pushed up rents and property prices, making it virtually impossible for Valletta's young people to set up home there. Other residents expressed concern how nightlife in Valletta is causing the loss of the city's character. One interviewee criticised the revival of Strait Street as being simply an imposition of the standard nightlife model upon Valletta without regard to context. The historic town's personality has been overtaken by commercialisation and business. One resident claimed that: "Money which could have helped people, was frittered away and in effect, the lasting legacy has been speeding up the touristification of the city and the expulsion of its people" (Deguara et al, 2019: 29). None of the respondents were dismissive of regeneration projects in themselves but contended that infrastructural designs should take into account the social aspect of the city, as well as enable human interaction (Deguara et al, 2019). Residents and middle-to-lower class sections of the population see their capital city and areas once inhabited by popular and working classes 
becoming gentrified and out of reach (Zahra, 2016). On Valletta's liveability, similar conclusions were drawn by a second V18 study that dealt with cultural infrastructural and its role in cultureled regeneration (Zammit \& Taldeiri, 2019). The study concluded that the strategy for Valletta was a "shortsighted view" on the future of the city and that it was more about generating investment than helping liveability. The study is critical of the fact that the V18 regeneration projects were not incorporated into an overall strategic vision for Valletta. The study laments the lack of meaningful community participation noting that; "Overall, the impression is that community involvement is often assumed to be taking place, and is approved of in principle, but is marginal in practice, with much loss of effectiveness in regeneration schemes" (Zammit \& Taldeiri, 2019: 67). Many concerns raised in these studies on Valletta's liveability were already present to some extent before the preparations for V18 gained momentum. The approach taken for $\mathrm{ECoC}$, however, made liveability conditions worse as there was no acknowledgment of these issues, nor was there any attempt to address them.

Public and private sector investments were instrumental in giving new life to Valletta in the evenings. The increase in catering establishments and also in night time activity began before 2010 at a time when there were significant public investments in public spaces. It accelerated after 2015 because the Foundation prioritised and actively encouraged investments in catering establishments in Strait Street and in other areas. Increased evening activity in Valletta is a welcome change, except that there is a widespread perception, especially amongst Valletta residents, that it has now become excessive. In particular evening leisure in Valletta is causing inconveniences to residents (Dingli, 2016). Another persistent problem is the take up of pedestrian spaces for table and chairs, often with unsightly canopies incompatible with the historic context. 
There is evidence that Valletta was transforming from a residential to a catering destination (Zammit \& Taldeiri, 2019).

For a historic area, urban regeneration is mainly about investments in the renewal of the urban fabric and bringing disused properties into use. It is also about generating vitality in urban spaces throughout the day and evening. Evening leisure activity is one small part of a much wider

renewal process. Although evening activity is important, there are countless other issues relating to urban regeneration that need to be addressed. Equating urban regeneration with the generation of evening/night-time activity is not only wrong but also harmful to Valletta, as it distorts the priorities that should be addressed to sustain regeneration and Valletta's liveability (Ebejer, 2019).

\section{Access and participation}

. In the preparation of the programme, efforts were made to reach out to different sectors of society and encourage those unfamiliar with the creative sector to engage in the creative processes and eventually attend the cultural events. At a later stage, outreach to new audiences was curtailed to an exercise in popular, broad-stroke marketing that delivered what was expected to easily targeted audience segments (Reljic, 2019). There was little or no creativity in mixing audiences up and encouraging different people to engage with programmes generally outside their cultural, social or financial experiences (Xuereb, 2018a).

The V18 programme included a large-scale reunion of the four traditional, local, religiously-inspired feasting communities in Valletta in an event called Il-Festa 1-Kbira, literally translated as "the big feast" (Blagojevic Vella \& Godhwani, 2019). In it there was no gesture of recognition, inclusion or welcome to numerous non-Maltese communities. Greek, Russian, Serbian, Eritrean, Somali and Italian communities were simply ignored as if they did not form part 
of Maltese cultural identity. The event was presented as a celebration of community but it was in fact the pursuit of an underlying political agenda and an effort to forge alliances on the basis of traditions and politics. Leydolt-Fuchs (2018) comments on the risk of the political take-over of cultural initiatives like ECoC. She argues that certain political behaviour can be very shrewd in exploiting cultural initiatives and titles related to the EU or UNESCO in order to promote, at the end of the day, what is little more than strategic political propaganda. By being silent about such behaviour, the EU risks endorsing it and contributing to the devaluation of its own programmes.

\section{Effects of Valletta 2018 on Malta's tourism}

In terms of tourism, Malta is substantially different to many other cities hosting the ECoC. When nominated, many ECoC cities had a tourism sector that was not well developed or, if well developed, was reliant mostly on urban tourism. In contrast, Malta is already a destination with an economy that is significantly reliant on tourism (Briguglio and Avellino, 2019) most of which is motivated by the Island's pleasant weather (Ebejer, 2018). ECoC effects on Malta's tourism would be to develop an already existing tourism industry rather than giving an injection to a tourism industry that is in its beginnings. Malta has a well-developed tourism accommodation sector meaning that any increase in visitors could be relatively easily absorbed within the current tourism accommodation offer. The second difference is that Malta does not have a hinterland and the population catchment is of less than half a million people. Malta is an island destination and therefore virtually all overnight visitors arrive by air. In the case of Malta therefore, changing trends in tourist arrivals could arguably be a good indicator of the economic effects of V18. The number of incoming tourists to Malta increased from 1.8 million visitors in 2015 to 2.6 million in 2018, an increase of 44 per cent. At face value, one could argue that this demonstrates that ECoC 
had a positive effect on tourism and on Malta's economy because of the increased tourist arrivals (Sultana \& Saliba, 2019). A closer look at the context is required to establish the validity of such a conclusion. There are other factors to which the increase in Malta's tourism can be attributed. For example, there were significant improvements in Malta's tourism product with numerous tourism-related projects being carried out to protect and improve Malta's urban heritage and making it more amenable to visitors (Ebejer and Tunbridge, 2020). Several hundred million euros, mostly from EU structural funds, were spent over two decades on many diverse projects involving fortifications, historical buildings, archaeological sites and public spaces. The increase in tourism numbers could be attributed in part to an improved tourism product although it is not possible to quantify. By the same token it is not possible to establish to what extent the increase in tourism numbers is attributable to $\mathrm{ECoC}$.

Another factor that impinges on the number of tourists is the number of international airports with direct flights to Malta. In 2006, the Government started offering incentives to low cost airlines to start flying to Malta. At the time tourist arrivals stood at 1.1 million and Malta was connected to 79 airports, mostly in Europe. Table 1 demonstrates a clear correlation between the number of incoming tourists and the number of airports with direct flights to Malta. This is especially so between 2015 when directly connected airports increased from 94 to 113 and the corresponding tourist numbers increased from 1.8 to 2.6 million. The opening of a new route is determined through negotiations between the low cost airline and the authorities. It is common practice, across Europe, for airport or national authorities to provide incentives to airlines to fly to their airport - the more attractive the incentives, the more likely will the low cost airline agree to launch a new route. It is our view that, although both $\mathrm{ECoC}$ and tourism product improvements 
facilitated tourism growth in the years preceding 2018, the rapid increase in tourism numbers was mostly due to a significant number of airports with direct flight connections to Malta.

(Table 1 to be inserted here.)

\section{Governance of Valletta 2018}

The EU operates subsidiarity with full respect to the notion that 'national cultures ..... have, of course, been the primary frame of reference in which cultural policy agendas have been elaborated in modern Europe' (Meinhof \& Triandafyllidou, 2006: 3). Cultural matters dealt with by the Council of the EU and related bodies respect the competences of member states on the basis of national identity in order to allow them all the necessary room within which to implement and monitor progress in ways that safeguard national priorities. While understandable and even laudable in its intention as a mechanism of the cultural governance of such a complex reality as is the EU, the subsidiarity principle may be contributing to a disaggregation of cultural practice and the formation of disconnected islands of culture. This is so because member states are known to shape guidelines, funding and mobilise resources to achieve primarily nationalistic aims. Such a trend is arguably on the rise (Leydolt-Fuchs, 2018). The results may thus only partially match expectations harboured at the outset as well as justify nationalistic action that contradicts goals for greater cohesion through culture in Europe. The example of the ECOC in Malta in 2018 is indicative of this scenario. In preparing for Valletta 2018 as ECOC, a great deal of programming and reporting to the European Commission focused on delivering this vision. However, later developments led to significant concerns. 
Only a few weeks after the title was conferred in May 2017, and the Melina Mercouri prize of 1.5 million euros settled, significant changes to the European dimension of the preparatory phase started taking place. The situation became more problematic during the ECoC year with various international figures in the cultural and political fields challenging the claim on European values professed by the Maltese authorities in the light of a disparaging and divisive attitude fomented by the Foundation chairperson with regard to the murder of a Maltese investigative journalist, in October 2017. Senior government defended the divisive comments on the grounds of freedom of speech (Xuereb, 2018b). In spite of harsh criticism from international and Maltese stakeholders, the EU itself did not adopt any official position (Xuereb, 2018a).

This episode, and the shadow it cast on the rest of the ECOC programme in Malta, contributes to expose some of the limits of the EU on matters of cultural significance. It may be correct to assert that "values or conceptions of what is good may vary according to cultural or social contexts" (Sjursen, 2006: 247) and that the practice of normative power cannot be anything other than 'the EU promoting its own norms in a similar manner to historical empires and contemporary powers' (Manners, 2002: 240). However, this example from Malta uncovers some of the severe tensions that the EU faces when promoting programmes that take place on a national level the value of which it seems not to be able to safeguard. The idea of a 'global common good' is tied up in unachievable cosmopolitanism and falls foul to accusations of cultural imperialism, an issue that discredits the EU as a normative power. However, in this case, the claim to "discount the EU as a normative power as it contradicts itself" may not be due to too much influence, but to too little (Aggestam, 2008: 1).

In the run-up to the ECoC year, the Foundation went through some considerable changes in personnel. Following its election in 2013, a new Labour government made a number of changes 
to the Foundation's leadership and staffing. The newly appointed Chairman was a political activist with no knowledge and understanding of the cultural sector, nor of issues related to tourism (Ebejer, 2019). In 2014, the contracts of the Artistic Director, and all seven Artistic Programme Directors were terminated. In June 2017, two very senior officials of the V18 management were dismissed. These officials were widely seen to be doing a good job so their removal was inexplicable. Years of know-how and experience were lost just a few months before the start of ECoC year (Ebejer, 2019). According to the European Commission evaluation report (Fox \& Rampton, 2019: 51), "Some stakeholders (cultural experts, local politicians, national media, international artists and departing members of staff) reported that the dismissals ..... were politically-motivated and damaging to the ECoC, its artistic vision and its cultural programme."

Politics and the furthering of government's political agenda of V18 had far reaching consequences on the eventual outcome. Having a political activist as chairperson was problematic because his agenda was dictated more by political concerns than furthering the interests of culture and of Malta's cultural community. He saw himself more as a political operator rather than the leading figure of the most important cultural event that Malta was ever involved in. This prevented him from acknowledging the harm of his controversial comments and hence he made no effort to undo the mistake. Apart from governance, politicisation also effected other aspects of V18. The programme in the bid-book was driven primarily by cultural considerations whereas the eventual programme was more populist aimed at attracting the crowds. This explains the theme change from 'imagine' to 'island-wide festa'. After 2016, the political climate in Malta intensified (Fox \& Rampton, 2019:34) and the staging of large-scale V18 was seen by the political authorities as a means of trying to create an air of normality. 


\section{Conclusion}

The main focus of the paper is cultural and social effects of V18 but it also considers, albeit to a lesser degree, aspects relating to tourism impact, urban regeneration and governance. There is evidence to show that there were positive effects on the cultural sector because of a cultural programme that was more varied and innovative when compared with previous years. It is not clear to what extent these benefits came about as a result of the $\mathrm{ECoC}$ brand or whether the same benefits could have been equally achieved merely with an increase in financial allocations to Malta's cultural sector. Similar to other ECoCs (European Commission, 2014; European Commission, 2018), politicisation of V18 was detrimental to the governance of the event with major changes being made in personnel in 2014 and then again just a few months before ECoC year. Changes made in V18 theme and in the cultural programme were most likely motivated by political considerations, namely to have more popular and crowd-pulling activities. Controversial comments made by the V18 significantly reduced V18's potential of capitalizing on the ECoC brand name as his comments were widely condemned because there were seen as in conflict with the ECoC values of inclusivity. Compared to, say, twenty years ago, Valletta has been regenerated with more investments in the rehabilitation of historic properties mostly for boutique hotels, tourism rentals and catering establishments. These investment came about primarily because of the investments made by the public sector in several major projects including extensive pedestrianisation and the restoration of important historic landmarks in Valletta. ECoC also played a part as investors realised that such an event provides commercial opportunities primarily in tourism accommodation and evening leisure. A revitalised Valletta has come at a price namely the reduced liveability of Valletta. There are justified concerns that the social fabric of Valletta 
will continue to decline. This is a negative social effect not only of ECoC but of the entire regeneration process of Valletta.

In writing this paper it is not the authors' intention to present an impacts assessment anywhere near comprehensive. The discussion of V18 has, however, enabled the authors to reflect on the process of assessing impacts of a major cultural such as ECoC. There are several aspects of ECoC that make the assessment of impacts problematic. Different dimensions of ECoC are related to one another and closely interlinked. One cannot consider the social dimension without considering issues relating to economic activity and also governance. In the case of Valletta, a discussion on reduced liveability cannot be divorced from the positive effects of increased private investments in historic buildings conservation. Another difficulty refers to effects that require a qualitative rather than a quantitative evaluation. This introduces an element of subjectivity with different stakeholders emphasising those aspects that are more directly relevant to them. For example the revitalisation of Valletta in the evening is seen positively by stakeholders keen to enhance the tourist experience. Whilst acknowledging the positive aspects of revitalized evening activity, residents are very concerned on how this impacts their quality of life and hence the liveability of Valletta. A third constraint in assessing effects is the difficulty to establish which Valletta changes were due to ECoC and which were due to other extraneous forces (Fox \& Rampton, 2019: 111). Section 6 explains that the increase in tourists was due to the sharp increase in the number of air routes connecting Malta to Europe. It is argued that had the number of air routes remained at the same levels as 2015 (at around 94), the increase in the number of tourists to Malta would have increased only slightly.

There are other aspects of V18 that merit further debate and research. A more in-depth discussion is required on the legacy of V18, including the setting up of the Valletta Cultural 
Agency. This was set up, among others, "to carry forward the legacy created by Valletta 2018". (Fox \& Rampton, 2019:72). There are, however, already existing national cultural agencies (Arts Council Malta, Events Malta and others) and the expansion of cultural activities could have very easily been catered for by dedicating more human and financial resources to existing agencies. Moreover the appointment of a political activist as its chairperson raises doubts on whether the intentions of this new agency are cultural or political. Other legacy issues that merit further discussion and research are the fund allocations to the event and the extent to which the eventual V18 programme adhered to the application upon which the ECoC title was awarded.

\section{References}

Aarhus University (2018) Aarhus 2017 Before - During - After. A research-based evaluation of the effects of the European Capital of Culture project. Retrieved from: https://projects.au.dk/fileadmin/projects/IMPACT_2017/Aarhus2017_before_during_after.pdf

Aggestam, L. (2008) Introduction: ethical power Europe? International Affairs, 84 (1), 1-11.

Allison, E. (2011) Historic Preservation and the Livable City. Wiley.

Ashworth, G. \& Tunbridge, J. (2017) Multiple approaches to heritage in urban regeneration: the case of City Gate, Valletta, Journal of Urban Design, 22(4), 494-501.

Bianchini, F., Albano, R. \& Bollo, A. (2013) The Regenerative Impacts of the European City/Capital of Culture Events. In M. Leary \& J. McCarthy (eds.) The Routledge Companion to Urban Regeneration.

Bidbook Imagine 18. (2011) Retrieved from http://valletta2018.org/the-bid-book-story/ .

Blagojevic Vella, D. \& Godhwani, V. (2019) A comprehensive analysis of the Valletta 2018 cultural programme. In Valletta 2018 Foundation, The Impacts of the European Capital of Culture, Final Research Report, Valletta 2018, 28-41. 
Briguglio, L. \& Avellino M. (2019) Has Overtourism reached the Maltese Islands? In Occasional Papers on Islands and Small States, University of Malta.

Campbell, P. (2011) Creative industries in a ECoC. International Journal of Cultural Policy, 17(5), 510522.

Chairman of committee that selected Valletta as European Capital of Culture boycotting V18 (2018a, April 24) Malta Independent.

Cordina, J. (2014, November 23) Valletta 2018: A realistic transformation for European capital of culture. Malta Independent.

Deguara, M., Pace Bonello, M. \& Magri, R. (2019) Community inclusion and accessibility in Valletta 2018. In Valletta 2018 Foundation, The Impacts of the European Capital of Culture, Final Research Report, Valletta 2018, 6-48.

Dingli, A (2016) Closing address by the Mayor of Valletta. In Ebejer, J (Ed.) Proceedings of Valletta Alive Foundation Seminar: Valletta Beyond 2020, 48-49.

Ebejer, J. (2016) Regenerating Valletta: a vision for Valletta beyond 2020. In Ebejer, J (Ed.) Proceedings of Valletta Alive Foundation Seminar: Valletta Beyond 2020, 35-44.

Ebejer, J. (2018) Urban heritage and cultural tourism development: a case study of Valletta's role in Malta's tourism. Journal of Tourism and Cultural Change, 1-15.

Ebejer, J. (2019, February 3) Valletta 2018: Was it successful? Malta Independent, pp. 8-9.

Ebejer, J. \& Tunbridge, J. (2020) The role of urban heritage in Malta's tourism: issues and initiatives. In G. Cassar \& M. Avellino (eds.) Tourism and the Maltese Islands-Observations, reflections and proposals. Malta: Institute for Tourism, Travel \& Culture - University of Malta \& Kite Group.

European Commission. (2014) European Capitals of Culture 2020-2033. Guide for cities preparing for the bid. Retrieved from https://ec.europa.eu/programmes/creative-europe/sites/creativeeurope/files/library/capitals-culture-candidates-guide_en.pdf.

European Commission (2018) Ex Post evaluation of the 2016 European Capitals of Culture (Donostia San Sebastian and Wroclaw). Brussels. Retrieved from: 
https://www.europarl.europa.eu/RegData/docs_autres_institutions/commission_europeenne/com/2018/02 35/COM_COM(2018)0235_EN.pdf .

Farmaki, A., Christou, P., Saveriades, A., \& Spanou-Tripinioti, E. (2019) Perceptions of Pafos as European Capital of Culture: Tourism stakeholder and resident perspectives. International Journal of Tourism Research, 21(2), 234-244. doi: 10.1002/jtr.2257.

Fox, T. \& Rampton, J (2019) Ex-post Evaluation of the 2018 European Capitals of Culture. A Final Report by the EFECTIV Consortium. European Commission, Brussels. Retrieved from: https://op.europa.eu/en/publication-detail/-/publication/93aa14ef-1b67-11ea-8c1f01aa75ed71a1/language-en.

Garcia, B., Melville, R. \& Cox, T. (2010) Impacts 08 European Capital of Culture Research Programme. Retrieved from: https://www.liverpool.ac.uk/media/livacuk/impacts08/pdf/pdf/Creating_an_Impact__web.pdf.

Garcia, B. (2005) Deconstructing the City of Culture: The Long-term Cultural Legacies of Glasgow 1990, Journal of Urban Studies, 42, 5-6: 841-868.

Hudec, O.; Remoaldo, P.; Urban`cíková,. N. \& Cadima Ribeiro, J. (2019) Stepping Out of the Shadows: Legacy of the European Capitals of Culture, Guimarães 2012 and Košice 2013. Sustainability, 11, 1469. doi:10.3390/su11051469 .

Immler, N. L. \& Sakkers, H., (2014) (Re)Programming Europe: European Capitals of Culture: rethinking the role of culture, Journal of European Studies, 44 (1): 3-29;

Johansson, M. \& Kociatkiewicz, J. (2011) City festivals: creativity and control in staged urban experiences. European Urban and Regional Studies, 18(4) 392-405.

Lähdesmäki, T. (2013) Cultural activism as a counter-discourse to the European Capital of Culture programme: The case of Turku 2011, European Journal of Cultural Studies, 16 (5): 598-619;

Leone Ganado, P. (2018, December 23) Valletta 2018: what has it left behind? Events, infrastructure and controversies too. Times of Malta.

Leydolt-Fuchs, P. (2018) Wieviel Politik verträgt Kulturhauptstadt? Kulturhauptstädte Europas 2018: Valletta und Leeuwarden. Kulturpolitische Mitteilungen, 161 (II), 26. 
Liu, Y (2014) Socio-Cultural Impacts of Major Event: Evidence from the 2008 European Capital of Culture, Liverpool. Social Indicator Research 115:983-998.

Markwick, M. (2017) Valletta ECoC 2018 and cultural tourism development, Journal of Tourism and Cultural Change, DOI: 10.1080/14766825.2017.1293674.

Meinhof, U. \& Triandafyllidou, A. (2006) Transcultural Europe: An Introduction to Cultural Policy in a Changing Europe. In: Meinhof, U. \& A. Triandafyllidou, A. (Eds.) Transcultural Europe: Cultural Policy in a Changing Europe, Palgrave Macmillan, 3-23.

Monitoring and Advisory Panel (2017) Valletta European Capital of Culture 2018, Brussels. https://ec.europa.eu/programmes/ creative-europe/sites/creative-europe/files/library/ecoc2018-vallettasecond-monitoring_en.pdf.

Municipality of Leeuwarden \& Province of Fryslân (2019) Final Assessment LF2018. Retrieved from: https://www.friesland.nl/uploads/media/5c8a6c2d209c4/bijlage-slotmeting-lf2018engels.pdf?token=/uploads/media/5c8a6c2d209c4/bijlage-slotmeting-lf2018-engels.pdf.

O'Callaghan, C. (2012) Urban anxieties and creative tensions in the European Capital of Culture 2005: 'It couldn't just be about Cork, like, International Journal of Cultural Policy, 18 (2): 185-204.

Palmer, R. (2004) European cities and capitals of culture: Study prepared for the European Commission, part 1. Brussels: Palmer-Rae Associates.

Quinn, B. (2005) Arts Festivals and the City. Urban Studies, May, 42 (5/6) , 927-943.

Reljic, T (2019, January 2) Looking back at 2018 ‘After Valletta 2018, we will never be the same again.' Maltatoday.

Richards, G. \& Palmer, R. (2010) Eventful Cities. Routledge.

Sacco, P. \& Tavano Blessi G. (2007) European culture capitals and local development strategies: Comparing the Genoa 2004 and Lille 2004 cases, Homo Oeconomicus 24(1): 111-41.

Sassatelli, M. (2006) The Logic of Europeanizing Cultural Policy. In: Meinhof U. \& Triandafyllidou, A., (Eds.) Transcultural Europe: Cultural Policy in a Changing Europe, 24-42. 
Sjursen, H. (2006) The EU as a 'normative power': how can this be? Journal of European Public Policy, $13(2), 235-251$.

Smith, A (2012) Events and Urban Regeneration: The strategic use of events to revitalise cities. Routledge.

Smith, A. \& Ebejer, J. (2012) Outward versus inward orientation of island capitals: the case of Valletta, Current Issues in Tourism, 15:1-2, 137-152.

Sultana, T \& Saliba, R. (2019) The Impact of Valletta 2018 on the Tourism Sector. In Valletta 2018 Foundation, The Impacts of the European Capital of Culture Final Research Report Valletta 2018, 6-14.

V18 chairman refuses to comment directly on mayor's boycott (2018b, July 3) Malta Independent.

Van der Steen, T. \& Richards, R. (2019) Factors affecting resident support for a hallmark cultural event: the 2018 European Capital of Culture in Valletta, Malta, Journal of Policy Research in Tourism, Leisure and Events, DOI: 10.1080/19407963.2019.1696352

Xuereb, K. (2018a) The Impact of the European Union on Cultural Policy in Malta. Croatian International Relations Review, XXIV (82), 38-61.

Xuereb, K. (2018b) Neocolonialist Practices in Cultural Governance in Malta as an EU State. In Congress proceedings: Beyond EYCH2018. What is the cultural horizon? Opening up perspectives to face ongoing transformations. ENCATC, 5-20.

Xuereb, K. (2018c, November 15) The betrayal of the muses. Malta Independent.

Zahra, J. (2016, May 10) And what about the residents of Valletta? Newsbook.

Zammit, A. \& Taldeiri, T. (2019) Assessing the relationship between community inclusion and space through Valletta 2018 cultural infrastructural projects. In: Valletta 2018 Foundation, The Impacts of the European Capital of Culture Final Research Report Valletta 2018, 50-72.

Žilič-Fišer, S. \& Erjavec,K. (2015) The political impact of the European Capital of Culture: 'Maribor 2012 gave us the power to change the regime'. International Journal of Cultural Policy, 23(5): 581-596. 